\title{
TRANSAKCJE, KTÓRE MOGĄ POGORSZYĆ STAN MAJĄTKOWY KOŚCIELNEJ OSOBY PRAWNEJ (KAN. 1295) ${ }^{1}$
}

\section{Wstęp}

Kanon 1295 Kodeksu Prawa Kanonicznego² dotyczy transakcji, które mogą pogorszyć conditio patrimonialis kościelnej osoby prawnej. Wspomniane transakcje różnią się od alienacji tym, że obarczone są realnym ryzykiem pogorszenia stanu majątkowego kościelnej osoby prawnej. Błędne ich interpretacje, jak i bezprawne działania mogą rzutować zarówno na kondycję majątkową kościelnej osoby prawnej, jak i na wiarygodność zarządców, którzy reprezentują kościelną osobę prawną. Dlatego jednym z głównych zadań zarządców jest wymóg, aby „przestrzegali przepisów zarówno prawa kanonicznego, jak i państwowego, albo wydanych przez fundatora, ofiarodawcę lub uprawnioną władzę" (kan. $1284 \S 2,3^{\circ}$ ). Brak wiedzy oraz samowolne dokonywanie zmian w patrimonium stabile może powodować dla zarządcy poważne konsekwencje, a w przypadku gdy zarządcą jest proboszcz, wiąże się to nawet $\mathrm{z}$ usunięciem z urzędu (por. kan. 1741, $5^{\circ}$ ).

Transakcje, które będą przedmiotem analizy w niniejszym artykule, dotyczą czynności prawnych dokonanych na patrimonium kościelnej

\footnotetext{
*Ks., dr, Katolicki Uniwersytet Lubelski Jana Pawła II; kaleta@kul.pl.

${ }^{1}$ Praca jest efektem realizacji projektu naukowego o $\mathrm{nr}$ rejestracyjnym 2014/15/D/ HS5/00664 (nr umowy UMO-2014/15/D/HS5/00664) finansowanego ze środków Narodowego Centrum Nauki.

2 Codex Iuris Canonici auctoritate Ioannis Pauli PP. II promulgatus, AAS 75 (1983), II, s. 1-317; Kodeks Prawa Kanonicznego, przekład polski zatwierdzony przez Konferencję Episkopatu Polski, Poznań 1984 [dalej cyt. KPK/83].
} 
osoby prawnej, które niosą ze sobą realne ryzyko jego pogorszenia. Za-

rządca, dokonując tego typu czynności prawnych, jest zobowiązany zachować normy o alienacji (kan. 1291-1294), chociaż akty te nie są alienacją. Ustawodawca jednak nie precyzuje przykładów tychże transakcji, ale odwołuje się do statutów kościelnych osób prawnych, które „powinny być dostosowane do wymogów kan. 1291-1294". Zanim jednak zostanie podjęta analiza kan. 1295 należy wpierw przedstawić proces powstania wspomnianej normy prawnej, w celu wskazania na jej znaczenie prawne w kanonicznym systemie prawnym, aby ostatecznie podać praktyczne przykłady stosowania kan. 1295.

\section{Legislacyjny rozwój dyscypliny kan. 1295}

Kanon 1295 KPK/1983 nie jest nową formułą prawną - jego odpowiednikiem był can. 1533 CIC/1917³, którego treść brzmiała następująco: „Normy zawarte w can. 1530-1532 są wymagane nie tylko przy alienacji we właściwym znaczeniu (łac. alienatione proprie dicta), lecz także w każdej umowie (łac. contractus), na skutek której stan Kościoła może znaleźć się w gorszej sytuacji" ${ }^{4}$. Z brzmienia tego kanonu można wywnioskować, że ustawodawca odróżniał alienację (łac. proprie dicta) we właściwym znaczeniu od umowy (łac. contractus), przez którą stan Kościoła może ulec pogorszeniu (łac. quo conditio Ecclesiae peior fieri possit). Takie rozróżnienie doprowadziło niektórych kanonistów do określenia umów, które mogą pogorszyć stan Kościoła jako alienację sensu largo ${ }^{5}$. Należy jednak pod-

${ }^{3}$ Papieska Rada Tekstów Prawnych w Codex iuris canonici fontium annotatione et indice analitico-alfabetico auctus, Vatican 1989 wyjaśniła, że pozostałymi źródłami kan. 1295 są: Normy Świętej Kongregacji z dnia 24 maja 1939 r., dotyczące ochrony rzeczy kosztownych (historycznych i artystycznych) we Włoszech. Normy te wskazują że przy zaciąganiu pożyczek, którego zabezpieczaniem są rzeczy kosztowne, wymagane jest uprzednie zezwolenie Stolicy Apostolskiej, ponieważ ten rodzaj czynności prawnej jest aktem nadzwyczajnego zarządzania.

${ }^{4}$ Tłumaczenie autorskie zob. can. 1533: Sollemnitates ad normam can. 1530-1532 requiruntur non solum in alienatione proprie dicta, sed etiam in quolibet contractu quo conditio Ecclesiae peior fieri possit.

${ }^{5}$ Niektórzy kanoniści nadal używają określenia „alienacja sensu stricto” (kan. 12911294) i "alienacja sensu largo” (kan. 1295). Zob. F. Bączkowicz, J. Baron, W. Stawinoga, Prawo kanoniczne. Podręcznik dla duchowieństwa, t. 2, Kraków 19583, s. 578; W. Wójcik, Dobra 
kreślić, że jest to określenie techniczne, ma ono na celu określenie, że niektóre czynności prawne mogą pogorszyć stan majątkowy. Niemniej jednak ustawodawca nie stosuje tego pojęcia w CIC/17.

W styczniu 1966 r. został powołany zespół do spraw dóbr kościelnych (Coetus de boni Ecclesiae temporalibus = Coetus), który miał na celu przeprowadzenie rewizji Codex Iuris Canonici z 1917 r. i przygotowanie projektu (łac. schema) nowego kodeksu. W sprawie can. 1533, Coetus obradowało dnia 16 maja 1968 r., podczas którego zgłoszono wątpliwości w sprawie zastosowanej frazy: „stan Kościoła może ulec pogorszeniu”. Próbowano wówczas doprecyzować, czy sformułowanie to ma na celu pogorszenie prawne, czy ekonomiczne Kościoła? W dyskusji ustalono, że frazę tę należy zastąpić następującym wyrażeniem: „ale również przy podejmowaniu jakiejkolwiek transakcji, na skutek której stan majątkowy kościelnej osoby prawnej może znaleźć się w gorszej sytuacji"6. Uznano, że takie sformułowanie bardziej odnosi się do stanu ekonomicznego Kościoła. Zmieniono również pojęcie „umowy” (łac. contractus) na pojęcie „transakcji” (łac. negotium) ${ }^{7}$. Po dokonanej modyfikacji, can. 1533 brzmiał następująco: „Normy zawarte w can. 1530-1532 wymagane są nie tylko przy alienacji, ale również przy jakiejkolwiek czynności prawnej na skutek której stan Kościoła może znaleźć się w gorszej sytuacji

Po zamknięciu dyskusji kanon ten nosił nazwę can. 40 Schema $1977^{9}$. Zauważyć jednak należy, że schemat tego kanonu omijał schemat can. 36, który odnosił się do zgody kompetentnej władzy dla dokonania alienacji patrimonium stabile kościelnej osoby prawnej, której wartość przekracza określoną przez konferencję biskupów kwotę. Dlatego pojawiła się przesłanka, zgodnie z którą can. 40 Schema 1977 może mieć zastosowanie do każdej transakcji zagrażającej patrimonium Kościoła, bez odniesienia do

doczesne Kościoła, [w:] W. Wójcik, J. Krukowski, F. Lempa, Komentarz do Kodeksu Prawa Kanonicznego, Lublin 1987, s. 86; S. Dubiel, Uprawnienia majątkowe Kościoła katolickiego w Polsce w świetle Kodeksu Prawa Kanonicznego z 1983 roku Konkordatu z 1993 roku i ustaw synodalnych, Lublin 2007, s. 72; L. Świto, Alienacja majątku kościelnego w diecezjach rzymskokatolickich w Polsce, Olsztyn 2010, s. 90; M. Tomkiewicz, Obrót majątkiem Kościoła rzymskokatolickiego $w$ Polsce, Olsztyn 2013, s. 20.

${ }^{6}$ Pontificium Consilium de Legum Textibus, “Communicationes" 2005, nr 37, s. 132.

7 J. Sondel (red.), Słownik łacińsko-polski dla prawników, Kraków 2009, s. 654.

8 "Communicationes" 2005, nr 37, s. 137: Can. 1533 - Solemnitates ad normam cann. 1530-1531 requiruntur non solum in alienatione, sed etiam in quolibet negotio quo conditio patrimonialis Ecclesiae peior fieri possit. Zob. “Communicationes” 2005, nr 37, s. 253.

${ }^{9}$ Pontificium Coetus Studiorum De iure Patrimoniali Ecclesiae, Schema canonum libri V. De iure patrimoniali Ecclesiae, Typis polyglottis Vaticanis 1977. 
jego konkretnych skutków finansowych i bez określenia właściwego organu dla wydania zgody na jego transakcję.

Kolejnym etapem rewizji can. 40 Schema 1977 były opinie udzielane przez organy konsultacyjne, które w ciągu roku miały przygotować własne komentarze dotyczące treści Schema 1977. Dnia 14 listopada 1979 r. dokonano kilku zmian w omawianym schemacie kanonu. Pierwszą z nich była zmiana pojęcia „Kościół” na pojęcie „kościelna osoba prawna”. Uzasadniono, że pogorszeniu majątkowemu nie ulega Kościół jako całość, ale konkretna kościelna osoba prawna. Natomiast drugą zmianą było dodanie zwrotu "statuty winne być dostosowane do osób prawnych". Chodziło więc o takie sformułowanie statutów, aby transakcje dokonane nieważnie według prawa kanonicznego były również nieważne w porządku prawa państwowego ${ }^{10}$. Projekt kanonu po naniesieniu zmian brzmiał następująco: „Wymagania can. 36, 37 i 39, do których statuty publicznych osób prawnych powinny być dostosowane, są wymagane nie tylko przy alienacji, lecz także przy jakiejkolwiek transakcji, na skutek której patrimonium osoby prawnej może znaleźć się w gorszej sytuacji”11.

Canon 40 Schema 1977 został powtórzony w can. 1246 Schema 198012, nie dokonując w nim żadnych zmian. W dyskusji nad jego treścią ważny głos zajął arcybiskup Joseph Bernardin, który krytycznie odniósł się do pojęcia „patrimonium stabile”. Stwierdził, że jest to określenie klasyczne i tradycyjne, co sprawia, że jest dzisiaj niewystarczające, szczególnie w przypadku zmieniających się warunków ekonomicznych. Dalej zasugerował, aby wprowadzić pojęcie transakcji, które jest bardziej elastyczne od pojęcia alienacji. Zauważyć należy, że był to pierwszy głos, który odnosił się do transakcji, które mogą pogorszyć stan majątkowy kościelnej osoby prawej.

${ }^{10}$ Pontificium Consilium de Legum Textibus, „Communicationes” 1980, nr 2, s. 426.

11 Sollemnitates ad normam can. 36, 38 et 39, quibus etiam statuta personarum iuridicarum conformanda sunt, servari debent non solum in alienation, sed etiam in quolibet negotio, quo condicio patrimonialis personae iuridicae peior fieri posit.

${ }_{12}$ Pontificia Commissio Codici Iuris Canonici Recognoscendo, Schema Codicis Iuris Canonici iuxta animadversiones S. R. E. Cardinalium, Episcoporum Conferentiarum, Dicasteriorum Curiae Romanae, Universitatum Facultatumque ecclesiasticarum necnon Superiorum Institutorum vitae consecrata recognitum, Vatican City. Typis polyglottis Vaticanis 1980. Can. 1246 - Requisita ad normam cann. 1242,1244 et 1245, quibus etiam statuta personarum iuridicum conformandi sunt, servari debent non solum in alienatione, sed etiam in quoulibet negirtio quo conditio patrimonialis personae iuridicae peior fieri possit. 
Canon 1295 Schema z 1982 jest identyczny z obowiązującym kan. 1295 KPK/1983. Podczas konsultacji z papieżem Janem Pawłem II nie dokonano w nim żadnych zmian.

\section{Znaczenie prawne kan. 1295}

Historia legislacyjna kan. 1295 potwierdza, że transakcje, które mogą pogorszyć patrimonium kościelnej osoby prawnej nie są aktami alienacji, choć odwołują się do zachowania procedury związanej z alienacją (kan. 1291-1294). Słusznie przypuszcza się, że gdyby transakcje te były aktami alienacji, ustawodawca kościelny jasno i wyraźnie określiłby to w KPK/83 ${ }^{13}$. Wymóg zawarty w kan. 1295 dotyczący zachowania przepisów o alienacji ma na celu ochronę dóbr kościelnych, aby nie uległy pogorszeniu lub utracie ${ }^{14}$. Należy podkreślić, że omawiane transakcje wynikające z dyspozycji prawnej zawartej w kan. 1295, nie przenoszą prawa własności i dotyczą tych transakcji, które są obarczone ryzykiem pogorszenia majątku stałego.

Dyspozycja prawna zawarta w kan. 1295 dotyczy publicznych osób prawnych. Pomimo że w kanonie tym expressis verbis nie występuje przymiotnik "publiczny”, to jednak z uwagi na treść kan. 1258, uznaje się, że kan. 1295 dotyczy publicznych osób prawnych. Ponadto Tytuł III Księgi V KPK/1983 dotyczy publicznych osób prawnych i nie ma w nim wzmianki o prywatnych osobach prawnych. Zgodnie z kan. 1257 § 2 „Dobra doczesne prywatnej osoby prawnej rządzą się własnymi statutami, a nie tymi kanonami, chyba że wyraźnie jest inaczej zastrzeżone".

Nie bez znaczenia jest zastosowane w kan. 1295 pojęcie patrimonium. Oznacza to, że przedmiotem transakcji są dobra określone prawnie jako patrimonium stabile (por. kan. 1291). Dobra kościelne określone jako patrimonium stabile stanowi zespół dóbr ruchomych i nieruchomych, które

${ }^{13}$ Krótkie podsumowanie kilku autorów wraz ze swoją opinią znaleźć można w: V. De Paolis, Los bienes temporales de la Iglesia, Madrid 2012, s. 272.

${ }^{14}$ Por. J.A. Renken, Church Property. A Commentary on Canon Law Governing Temporal Goods in the United States and Canada, Ottawa 2009, s. 282. 
są podstawą majątkową zabezpieczającą byt i działanie kościelnej osoby prawnej na przyszłość ${ }^{15}$.

Kanon 1295 stanowi, że statuty publicznych osób prawnych powinny być dostosowane do wymagań kan. 1291-1294. W przypadku gdyby w statutach kościelnej osoby prawnej nie wspomniano o tego rodzaju czynnościach, można odnieść się do statutów synodu diecezjalnego, przy czym w kan. 1295 jest mowa o statutach osoby prawnej. W przypadku braku statutów mimo wszystko należy zastosować wymagania zawarte w kan. 1291-1294.

Warto tu przywołać kan. 117, który stanowi, że „Żaden zespół osób lub rzeczy, pragnący otrzymać osobowość prawna, nie może jej uzyskać, chyba że jego statuty zostały zatwierdzone przez kompetentną władzę". Dlatego wnioskować należy, że każda osoba prawna powinna mieć własne statuty, które będą precyzowały, które akty prawne stanowią transakcje, które mogą pogorszyć stan majątkowy kościelnej osoby prawnej (kan. 1295). W Polsce dla przykładu, parafie, które są osobami prawnymi, nie mają własnego statutu, ale posługują się statutami synodu diecezjalnego, stąd wydaje się słuszny postulat de lege ferenda, aby parafie posiadały swój własny statut, w których wymogi kan. 1291-1294 będą dostosowane i uszczegółowione.

Należy jednak zauważyć, że uwaga o dostosowaniu statutów do wymogów kan. 1291-1294 została dodana jako rezultat sugestii konsultorów do Schema 1977. Zgłoszenie tej uwagi miało na celu zapewnienie, aby transakcje były dokonywane zgodnie z prawem kanonicznym i prawem cywilnym. Ponad to zamysłem Coetus było to, aby statuty - o których mowa w kan. 1295 - były rozumiane w znaczeniu prawa kanonicznego i konsekwentnie były uznawane przez prawo cywilne. Zmiana ta miała na celu unikanie poważnych błędów w zarządzaniu, kiedy dana czynność prawna jest ważna według prawa cywilnego, natomiast w prawie kanonicznym jest nieważna. Na tej podstawie pojawia się postulat, aby statuty kościelnych osób prawnych były tak sformułowane, aby transakcje dokonywane przez zarządców dóbr kościelnych były ważne zarówno na mocy prawa kanonicznego jak i cywilnego.

${ }^{15}$ P. Kaleta, Pojęcie »patrimonium stabile«, „Roczniki Nauk Prawnych” 2014, nr 4, s. $147-161$. 


\section{Procedura dokonania transakcji, która może pogorszyć stan majątkowy}

Chcąc dokonać transakcji, która może pogorszyć patrimonium kościelnej osoby prawnej należy zachować następującą procedurę:

a) Uzyskać zezwolenie kompetentnej władzy kościelnej (kan. 1291; 638 §3). W przypadku osób prawnych podległych biskupowi - jest nim biskup diecezjalny, który wydaje zezwolenie dopiero po uzyskaniu zgody diecezjalnej rady do spraw ekonomicznych i kolegium konsultorów i zainteresowanych osób, gdy wartość transakcji przekracza minimalną wartość alienacji ustaloną przez konferencję biskupów (kan. 1292). W przypadku instytutów zakonnych, zezwolenie wydaje wyższy przełożony za zgodą jego rady (kan. 638 $\S 3)$.

b) Jeśli wartość transakcji przekracza maksymalną wysokość alienacji ustaloną przez konferencję biskupów, wówczas zezwolenie wydaje oprócz biskupa diecezjalnego również Stolica Apostolska (kan. $1292 \S 2)$.

c) Stolica Apostolska zobowiązana jest wydać zgodę na podjęcie transakcji pogarszających stan patrimonium, gdy ich przedmiotem są dobra darowane Kościołowi na podstawie ślubu, a także, gdy dotyczy to rzeczy kosztownych z racji artystycznych lub historycznych niezależnie od ich wartości ekonomicznej. (kan. 1292 § 2).

d) W przypadku gdy transakcja dotyczy majątku podzielnego na odrębne części, zarządca w prośbie o zezwolenie zobowiązany jest wyszczególnić części już wcześniej alienowane. W przeciwnym razie udzielone zezwolenie jest nieważne (kan. 1292 §3).

e) Ci, którzy powinni mieć udział w alienowaniu dóbr przez wyrażenie zgody (diecezjalna rada do spraw ekonomicznych, kolegium konsultorów, osoby zainteresowane), nie powinni wyrażać zgody, jeśli nie zapoznali się dokładnie ze stanem materialnym osoby prawnej oraz z alienacjami już dokonanymi (kan. 1292 § 4).

f) Ustawodawca wymaga, aby zachować: słuszną przyczynę, jaką jest nagląca potrzeba, wyraźna korzyść, pobożność, miłość lub inna poważna racja pasterska (kan. $1293 \S 1,1^{\circ}$ ), pisemna ocena takiej transakcji dokonaną przez rzeczoznawców (kan. 1293 § 1, 2º ), oraz 
zachować inne środki ostrożności przepisane przez kompetentną władzę (kan. 1293 § 2).

\section{Stosowanie w praktyce kan. 1295}

Przedstawione powyżej znaczenie prawne kan. 1295 pozwala na postawienie praktycznych wniosków dotyczących stosowania kan. 1295. Jak już wcześniej wspomniano, kan. 1295 nie odnosi się do alienacji in proprie dicta, ale transakcji, które mogą pogorszyć patrimonium kościelnej osoby prawnej. W związku z tym nasuwa się pytanie, jakie rodzaje transakcji należy uznać za zagrażające patrimonium kościelnej osoby prawnej?

Początkowo, przed promulgacją obowiązującego Kodeksu, wielu kanonistów odwoływało się do motu proprio z 1964 r. bł. Pawła VI Pastorale munus ${ }^{16}$, w którym Papież upoważnił biskupów, aby ci udzielali zezwolenia na określone akty dotyczące dóbr kościelnych. Art. 32 Pastorale munus stanowi, że "[Biskup diecezjalny] jest upoważniony do udzielenia zezwolenia w prawnie uzasadnionych przypadkach na akty alienacji dóbr kościelnych; zastawu; zobowiązań hipotecznych; najmu, dzierżaw wieczystych (emfiteuz) i innych długów zaciąganych przez kościelną osobę moralną, których wartość została określona przez konferencję biskupów danego kraju i otrzymała recognitio Stolicy Apostolskiej"17.

Za tego rodzaju transakcję nie uznawano: kupna rzeczy za pieniądze będące w obrocie, nieulokowane na stałe jako kapitał dochodowy; spłacenie pożyczki takimiż pieniędzmi; zaciągnięcie pożyczki bez zabezpieczenia hipotetycznego; lokata pieniędzy; sprzedaż papierów wartościowych celem kupna gruntu lub domu czynszowego albo celem wybudowania potrzebnego domu mieszkalnego; sprzedaż starych sprzętów celem kupna nowych tej samej wartości; odrzucenie ofiary, darowizny; utrata rzeczy wskutek przemocy lub kradzieży; uszkodzenie rzeczy ${ }^{18}$.

16 Paulus PP. VI, Litterae apostolicae Motu proprio Pastorale munus (30.11.1963), AAS 56 (1964), s. 512 [dalej cyt. PM].

17 Tłumaczenie własne zob. art. 32 PM: Concedendi licentiam ut, legitima interveniente causa, bona ecclesiastica alienari, oppignerari, hypothecae nomine obligari, locari, emphyteusi redimi possint, et personae morales ecclesiasticae aes alienum contrahere valeant, usque aol eam pecuniae summam, quam nationalis aut regionalis Conferentia Episcoporum proposuerit et Apostolica Sedes adprobaverit.

${ }^{18}$ F. Bączkowicz, J. Baron, W. Stawinoga, Prawo kanoniczne..., s. 578. 
Praktyczną egemplifikacją kan. 1295 będą następujące czynności prawne:

a) zaciąganie pożyczki ${ }^{19}$;

b) ustanowienie hipoteki lub służebności gruntowej;

c) kredyt pod zastaw rzeczy kosztownych;

d) zawieranie długoterminowych umów o dzierżawę lub najmu ${ }^{20}$;

e) zmiana w statusie własności (np. przekształcanie niektórych form własności w spółki);

f) działanie jako poręczyciel długów innych osób fizycznych lub prawnych;

g) podejmowanie inwestycji finansowanych z projektów unijnych ${ }^{21}$.

To co wyróżnia przedstawione wyżej przykłady czynności prawnych, jest ryzyko [wyróżn. P.K.]. pogorszenia stanu posiadania dóbr kościelnych. Nie należy ich jednak traktować jako listy zamkniętej tychże czynności. Są one jedynie przykładowymi czynnościami prawnymi. Formułowanie kompletnej listy może być mylące. Jest ono bowiem uzależnione od potencjalnego wpływu na patrimonium kościelnej osoby prawnej ${ }^{22}$.

Jak już podkreślono w tekście, zastosowanie kan. 1295 jest stosunkowo względne i uzależnione od ryzyka, czyli realnego niebezpieczeństwa pogorszenia majątku lub sytuacji majątkowej kościelnej osoby prawnej ${ }^{23}$. Zagrożenie patrimonium stabile powinno być racjonalnie uzasadnione. Wskazane są tu konsultacje z osobami doświadczonymi w sprawach ekonomicznych lub oszacowanie ewentualnego ryzyka przez biegłych. Nale-

19 Zdaniem Mirosława Sitarza zaciągnięcie umowy pożyczki bez obciążenia (np. hipoteki) nie jest transakcją która może pogorszyć stan posiadania, M. Sitarz, Warunki alienacji majątku kościelnego według KPK/1983, "Roczniki Nauk Prawnych” 2000, nr 10, z. 2, s. 96. Innego zdania jest L. Świto, Alienacja majątku kościelnego..., s. 91.

${ }_{20}$ Zob. Congregatio pro Institutis Vitae Consecratae et Societatibus Vitae Apostolicae, Rescript Regarding Leasing, [w:] Canon Law Society of America. Advisory opinions, Washington 1992, s. 15-16.

${ }^{21}$ P. Kaleta, Kościelne prawo majątkowe, Lublin 2014, s. 224.

${ }^{22}$ R. Kennedy nie zgadza się z przedstawionymi w tekście rodzajami aktów prawnych, ponieważ wielu kanonistów, rodzaje aktów prawnych zapisanych w starym Kodeksie zaadoptowali do KPK/1983. Wymienione powyżej akty zostały uznane w CIC/1917 jako transakcje, które mogą spowodować, że majątek kościelnej osoby prawnej może znaleźć się w gorszej sytuacji, przy czym KPK/1983 nie podaje przykładowych transakcji. Ponadto uznawanie tych aktów w XX wieku jako pogarszających stan majątkowy kościelnej osoby prawnej jest pominięciem ewolucyjnego charakteru współczesnych narzędzi finansowych, The Temporal Goods of the Church, [w:] J. B. Beal, J.A. Coriden, T.J. Green (red.), New Commentary on the Code of Canon Law, New York 2000, s. 1503.

${ }_{23}$ J.P. Schouppe, Derecho Patrimonial Cannonico, Pamplona 2007, s. 159. 
ży również zwrócić uwagę, że to, co realnie zagraża jednej parafii, dla innej niekoniecznie musi być zagrożeniem ${ }^{24}$. Dlatego istotne są $\mathrm{w}$ tym zakresie statuty kościelnych osób prawnych, o których mowa w kan. 1295, które powinny być dostosowane do wymogów kan. 1291-1294.

\section{Interpretacje kan. $1295 \mathrm{w}$ kanonistyce}

Zdaniem Francisa Morriseya, transakcje, które mogą pogorszyć condicio patrimonialis kościelnej osoby prawnej pociągają za sobą trzy elementy:

a) utrata lub pogorszenie prawa własności;

b) utrata lub pogorszenie kontroli;

c) utrata lub pogorszenie "protektoratu" (dosł. sponsorship)"25.

Kan. 1295 ma szczególne znaczenie przy podejmowaniu wspólnych przedsięwzięć (ang. joint venture) i w sytuacji, kiedy dobra należące do kościelnej osoby prawnej są zarządzane wspólnie, np. gdy dwie lub trzy parafie wspólnie prowadzą działalność edukacyjna, charytatywną czy socjalną lub kiedy dwa, lub więcej instytutów życia konsekrowanego wspólnie prowadzi szpital lub inną instytucję opieki zdrowotnej ${ }^{26}$.

John Renken interpretuje, że transakcje, o których mowa w kan. 1295 skupiają swoje działanie ad intra na ochronie dóbr kościelnych, podczas gdy alienacja proprie dicta skupia swe działanie ad extra na przeniesieniu prawa własności. Co więcej, kan. 1295 nie stosuje się do jakiegokolwiek majątku kościelnego, ale do patrimonium stabile ${ }^{27}$.

Z kolei Jean-Claude Périsset uznaje, że ,jakakolwiek transakcja, która może pogorszyć stan majątkowy kościelnej osoby prawnej” dotyczy m.in. dzierżawy, zastawu, nie dotyczy zaś dominium ${ }^{28}$.

Domingo Andrés uważa, że kan. 1295 stosuje się do różnego rodzaju umów, zobowiązań, cesji, redukcji, płatności, kredytów, które mogą ze względu na ich treść i tryb mogą ostatecznie przyczynić się do pogors-

${ }^{24}$ Por. R.T. Kennedy, The Temporal Goods of the Church..., s. 1503.

${ }^{25}$ F.G. Morrisey, The Alienation of Temporal Goods in Contemporary Practice, "Studia Canonica" 1995, nr 2, s. 311.

${ }^{26}$ Tamże.

27 J.A. Renken, Church Property. A Commentary on Canon Law..., s. 282.

${ }_{28}$ J.C. Périsset, Les biens temporels de l'Église: Commentaire des canons 1254-1310, Paris 1996. s. 216-217. 
zenia stanu majątku kościelnej osoby prawnej. Pogorszenie lub pomniejszenie może przybrać dwie formy: a) zmniejszenie ilości aktywów majątkowych, b) zwiększenie zobowiązań lub wierzytelności. Treść kanonu przemawia za pogorszeniem teraz lub w przyszłości stanu posiadania ${ }^{29}$.

Na uwagę zasługuje również interpretacja Lucjana Świto, który uważa, że do alienacji sensu largo należą takie czynności jak: ustanowienie dzierżawy, najmu, zastawu, hipoteki, służebności gruntowej i osobistej, użytkowania, udzielenie poręczenia, użyczenia i pożyczki. Autor dodaje także inne postacie umów nienazwanych, z których zawarciem związane jest ryzyko pogorszenia sytuacji majątkowej Kościoła ${ }^{30}$.

Wspólną cechą przedstawionych interpretacji jest ryzyko pogorszenia majątku kościelnego. Pogorszenie stanu majątkowego wynika z innych przyczyn niż alienacja - są nimi transakcje (umowy), które z uwagi na wartość ekonomiczną mogą pogorszyć stan majątkowy kościelnej osoby prawnej. Zachowanie przepisów o alienacji (kan. 1291-1294) ma na celu ochronę dóbr kościelnych. Ponadto w interpretacji kan. 1295 wydaje się ważne, aby ustawy interpretować według własnego znaczenia słów, rozważanego w tekście i kontekście. Jeśli pozostaje ono wątpliwe i niejasne, należy uwzględnić miejsca paralelne, gdy takie sa, cel i okoliczności ustawy oraz myśl ustawodawcy (kan. 17).

\section{Transakcje a akty nadzwyczajnego zarządzania}

Ustawodawca w KPK/83, w żadnym miejscu nie określa, że alienacja jest aktem nadzwyczajnego zarządzania. Każdy z tych aktów tak nadzwyczajnego zarządzania, jak i alienacji ma swoją własną historię powstania ${ }^{31}$ i własne przepisy prawne w KPK/83. Przepisy o alienacji w KPK/83 zostały wyraźnie sprecyzowane i uzyskały nowe znaczenie: ${ }^{32}$. Natomiast prze-

${ }^{29}$ D.J. Andrés Gutiérrez, Las formas de vida consagrada. Comentario teológico-jurídico al Código de derecho canónico, Madrid 2005, s. 256-257.

${ }^{30}$ L. Świto, Alienacja majątku kościelnego..., s. 90-91.

31 Zob. F.R. Aznar Gil, La administratión de los bienes temporales de la Iglesia, Salamanca 1993, s. 401-403.

32 Alienacja jest również prawem Kościoła. W can. 1495 § 1 KPK/17 wyróżniono tylko trzy rodzaje praw przysługujące Kościołowi na podstawie prawa wrodzonego: prawo do nabywania, posiadania i zarządzania. Natomiast na mocy kan. 1254 § 1 KPK/83 Kościół na 
pisy dotyczące aktów nadzwyczajnego zarządzania stanowią treść tytułu II księgi V i zapisane są w kan. 1277 i 1281, natomiast normy odnoszące się do aktów alienacji stanowią przedmiot tytułu III księgi V i zawarte są w kan. 1291-1294. Zachodzące różnice między aktami nadzwyczajnego zarządzania a alienacją można przedstawić nie tylko na podstawie zastosowanej terminologii (zob. kan. 17), ale również na gruncie pojęciowego ich znaczenia.

Zarządzanie, nawet nadzwyczajne, ma na celu zachowanie dóbr kościelnych, podniesienie ich wydajności i przeznaczenie ich zgodnie z celami dóbr kościelnych ${ }^{33}$. Natomiast akty alienacji stosuje się $\mathrm{w}$ celu przeniesienia prawa własności z jednego podmiotu na drugi ${ }^{34}$, zarówno aktem darowizny, jak i zawartą umową sprzedaży lub zamiany ${ }^{35}$. W sytuacji, gdy nie było przeniesienia prawa własności z jednej osoby prawnej na druga wówczas nie można mówić o alienacji ${ }^{36}$. Alienacją nie jest utrata dóbr lub rzeczy na skutek przemocy, lub kradzieży - choć zdarzenia te pomniejszają stan posiadania, to jednak nie przenoszą w sposób legalny prawa własności ${ }^{37}$.

W zależności od okoliczności i sytuacji ekonomicznej osoby prawnej należy rozważyć przepisy o aktach nadzwyczajnego zarządzania (kan. $638 \S 1 ; 1277 ; 1281 \S 1)^{38}$ albo przepisy o jakiejkolwiek transakcji, która może pogorszyć majątek kościelnej osoby prawnej (kan. 1295) ${ }^{39}$. Przepisy o alienacji stosuje się wówczas, gdy rzecz alienowana stanowi patrimo-

podstawie prawa wrodzonego ma cztery rodzaje praw: prawo do nabywania, posiadania, zarządzania i alienowania. Te prawa zostały także powtórzone w kan. 1255.

${ }^{33}$ Pontificio Consiglio per i Testi Legislativi, Nota Esplicativa »La funzione dell'autorità ecclesiastica sui beni ecclesiastici ", "Communicationes" 2004, nr 36, s. 26.

${ }_{34}$ Zob. I.B. Waters, Canon 1292 and Canon 1294. Transfer of Property from Religious Congregation to Diocese, [w:] A.J. Espelage (red.), CLSA Advisory Opinions 1994-2000, , Washington 2002, s. 416-417.

${ }^{35}$ F. Grazian, La nozione di amministrazione e di alienazione nel Codice di diritto canonico, Roma 2002; zob. F.G. Morrisey, The Alienation of Temporal Goods in Contemporary Practice..., s. 293-316; zob. M. Sitarz, Warunki alienacji majątku kościelnego..., s. 95-111.

36 Ponadto, Francis Morrisey zwraca uwagę, że niektórzy kanoniści uważaja że ustanowienie powiernictwa jest alienacją „ponieważ dobra te nie są już do wyłącznej dyspozycji kościelnej osoby prawnej. Jednak wydaje się, że powiernictwo ustanowione rozważnie nie powinno być uznawane za alienację, jeśli majątek jest używany zgodnie z głównymi celami kościelnymi i są umieszczone w bardziej bezpiecznej formie własności" J.A. Renken, Church Property. A Commentary on Canon Law..., s. 249.

37 F. Pasternak, Urzędy i beneficja kościelne, majątek kościelny, Warszawa 1970, s. 293.

${ }^{38}$ V. De Paolis, Los bienes temporales de la Iglesia..., s. 273.

39 J.A. Renken, Church Property. A Commentary on Canon Law..., s. 253. 
nium stabile, a jej wartość przekracza minimalną kwotę określoną w prawie (kan. 1291).

Różnice między aktami alienacji a nadzwyczajnym zarządzaniem powstają na gruncie procedury dokonania aktu. Akty nadzwyczajnego zarządzania nie posiadają wymogów dotyczących godziwości aktu, a do ich ważności nie ma wymogu uzyskania zezwolenia od Stolicy Apostolskiej (kan. 1277; $1281 \S 1$ ). Natomiast widoczne są podobieństwa dotyczące uzyskania zezwolenia kompetentnej władzy. Akty nadzwyczajnego zarządzania posiadają sprecyzowany podmiot wydający pisemne upoważnienie (łac. facultas) $)^{40}$ - jest nim ordynariusz (kan. $1281 \S 1$ ), natomiast w celu dokonania aktów alienacji wymagana jest pisemna zgoda (łac. licentia $)^{41}$ biskupa diecezjalnego (kan. $1292 \S 1$ ). Poza tym akty alienacji mają określone trzy organy konsultacyjne, od których biskup diecezjalny zobowiązany jest uzyskać zgodę (łac. consensus) ${ }^{42}$. Są nimi:

1) diecezjalna rada do spraw ekonomicznych;

2) kolegium konsultorów; oraz

3) zainteresowane osoby (kan. $1292 \S 1)$.

Procedura aktów nadzwyczajnego zarządzania nie przewiduje zgody zainteresowanych osób (por. kan. 1277).

Z przeprowadzonej analizy przepisów wynika, że różnice między tymi czynnościami prawnym są wystarczająco czytelne i nie należy ich łączyć w jeden rodzaj aktów nadzwyczajnego zarządzania. Biorąc pod uwagę słuszność kanoniczna, trzeba zachować specyfikę każdego z tych aktów, zwłaszcza w odniesieniu do alienacji, która ma na celu przeniesienie prawa własności na inną osobę prawną lub fizyczną. W praktyce mogą pojawić się trudności z właściwą aplikacją przedstawionych przepisów prawnych, nie mniej zgoda kompetentnej władzy, która jest formą władzy nadzorczej, w przypadku pojawiających się wątpliwości powinna pomóc w korygowaniu rodzaju czynności prawnej.

Zdaniem Francisa Morisseya, większość czynności prawnych będzie dokonywana na podstawie kan. 1295 niż kan. 128143. Również nie wydaje

${ }^{40}$ Łaciński termin facultas- atis oznacza: „uprawnienie, zdolność, upoważnienie”. J. Sondel (red.), Stownik tacińsko-polski..., s. 371.

${ }^{41}$ Łaciński termin licentia- ae oznacza: „pozwolenie, zezwolenie, zgoda”. J. Sondel (red.), Slownik tacińsko-polski..., s. 577.

42 Łaciński termin consensus- us w polskim tłumaczeniu oznacza: „zezwolenie, zgoda”. J. Sondel (red.), Stownik tacińsko-polski..., s. 207.

${ }^{43}$ P. Kaleta, Kościelne prawo majątkowe..., s. 224. 
się bezzasadna argumentacja Velasio De Paolisa, który stwierdza, że większość aktów nadzwyczajnego zarządzania podlega normie prawnej zawartej w kan. 1295, chyba że są wyłączone przez konferencję biskupów lub przez własne statuty ${ }^{44}$.

W związku z powyższym można stwierdzić, że obok aktów zwyczajnego zarządzania i nadzwyczajnego zarządzania, istnieje także kategoria transakcji, które moga pogorszyć stan majątkowy kościelnej osoby prawnej. Transakcje tego rodzaju mają odrębne przepisy prawne niż akty nadzwyczajnego zarządzania.

\section{Zakończenie}

Reasumując powyższą analizę dotyczącą transakcji, które mogą pogorszyć stan majątkowy kościelnej osoby prawnej (kan. 1295), należy stwierdzić, że:

1. Poprzednikiem kan. 1295 był can. 1533 CIC/1917. Jedną z istotnych zmian było zastąpienie pojęcie „umowa” pojęciem "transakcji”, które bardziej odpowiada współczesnym zmianom ekonomicznym.

2. Ustawodawca nie podaje enumeratywnie rodzajów aktów prawnych, które należy stosować zgodnie z kan. 1295, ale stanowi, że statuty kościelnych osób prawnych powinny być dostosowane do wymogów kan. 1291-1294. W przypadku braku statutów kościelnej osoby prawnej należy odnieść się do statutów synodu diecezjalnego. W Polsce dla przykładu, parafie, które są osobami prawnymi, nie mają własnych statutów, ale posługują się statutami synodu diecezjalnego, stąd wydaje się słuszny postulat de lege ferenda, aby parafie posiadały swój własny statut, w których wymogi kan. 12911294 będą dostosowane i uszczegółowione. Dodać należy, że zamysłem Coetus było to, aby statuty - o których mowa w kan. 1295 - były rozumiane w znaczeniu prawa kanonicznego i konsekwentnie były uznawane przez prawo cywilne. Zmiana ta miała na celu unikanie poważnych błędów w zarządzaniu, kiedy dana czynność

${ }^{44}$ V. De Paolis, Los bienes temporales de la Iglesia..., s. 287. 
prawna jest ważna według prawa cywilnego, natomiast w prawie kanonicznym jest nieważna.

3. Transakcje, o których mowa w kan. 1295 nie są "alienacją sensu largo". Nie można jednak ich mylić z aktami nadzwyczajnego zarządzania, o których mowa w Tytule II Księgi V KPK/1983. Coetus de bonis Ecclesiae temporalibus uznała, że alienacja nie jest aktem nadzwyczajnego zarządzania. Obok aktów zwyczajnego zarządzania i nadzwyczajnego zarządzania, istnieje także kategoria transakcji, które mają odrębne przepisy prawne, różne od aktów nadzwyczajnego zarządzania.

4. W kanonistyce do przykładów transakcji, które mogą pogorszyć patrimonium kościelnej osoby prawnej uznaje się następujące rodzaje czynności prawnych: zaciąganie pożyczki; ustanowienie hipoteki lub służebności gruntowej; kredyt pod zastaw rzeczy kosztownych; zawieranie długoterminowych umów o dzierżawę lub najmu; zmiana w statusie własności (np. przekształcanie niektórych form własności w spółki); działanie jako poręczyciel długów innych osób fizycznych lub prawnych; podejmowanie inwestycji finansowanych z projektów unijnych. Są to jedynie przykładowe akty prawne, jednak formułowanie kompletnej listy może być mylące, jest to bowiem uzależnione od potencjalnego wpływu na patrimonium kościelnej osoby prawnej.

Słowa kluczowe: transakcje, umowy, alienacja, zarządzania dobrami kościelnymi

\section{Bibliografia}

Andrés Gutiérrez D.J., Las formas de vida consagrada. Comentario teológico-jurídico al Código de derecho canónico, Madrid 2005.

Aznar Gil F.R., La administratión de los bienes temporales de la Iglesia, Salamanca 1993.

Bączkowicz F., Baron J., Stawinoga W., Prawo kanoniczne. Podręcznik dla duchowieństwa, t. 2, Kraków 19583.

De Paolis V., Los bienes temporales de la Iglesia, Madrid 2012.

Dubiel S., Uprawnienia majątkowe Kościoła katolickiego w Polsce w świetle Kodeksu Prawa Kanonicznego z 1983 roku Konkordatu z 1993 roku i ustaw synodalnych, Lublin 2007. 
Grazian F., La nozione di amministrazione e di alienazione nel Codice di diritto canonico, Roma 2002.

Kaleta P., Kościelne prawo majątkowe, Lublin 2014.

Kaleta P., Pojęcie »patrimonium stabile», „Roczniki Nauk Prawnych” 2014, nr 4, s. $147-161$.

Kennedy R.T., The Temporal Goods of the Church, [w:] J. B. Beal, J.A. Coriden, T.J. Green (red.), New Commentary on the Code of Canon Law, , New York 2000, s. 1449-1525.

Morrisey F.G., The Alienation of Temporal Goods in Contemporary Practice, "Studia Canonica" 1995, nr 2, s. 293-316.

Pasternak F., Urzędy i beneficja kościelne, majątek kościelny, Warszawa 1970.

Périsset J.C. Les biens temporels de l'Église. Commentaire des canons 1254-1310, Paris 1996.

Renken J.A., Church Property. A Commentary on Canon Law Governing temporal Goods in the United States and Canada, Ottawa 2009.

Schouppe J.P., Derecho Patrimonial Cannonico, Pamplona 2007.

Sitarz M., Warunki alienacji majątku kościelnego wedtug KPK/1983, „Roczniki Nauk Prawnych" 2000, nr 1, s. 95-111.

Sondel J. (red.), Słownik łacińsko-polski dla prawników, Kraków 2009.

Świto L., Alienacja majątku kościelnego w diecezjach rzymskokatolickich w Polsce, Olsztyn 2010.

Tomkiewicz M., Obrót majątkiem Kościoła rzymskokatolickiego w Polsce, Olsztyn 2013.

Waters I.B., Canon 1292 and Canon 1294. Transfer of Property from Religious Congregation to Diocese, [w:] A.J. Espelage (red.), CLSA Advisory Opinions 19942000, Washington 2002, s. 416-417.

Wójcik W., Dobra doczesne Kościoła, [w:] W. Wójcik, J. Krukowski, F. Lempa, Komentarz do Kodeksu Prawa Kanonicznego, Lublin 1987.

\section{TRANSACTIONS WHICH THE PATRIMONIAL CONDITION OF THE JURIDICAL PERSON MAY BE JEOPARDISED (CAN. 1295)}

\section{S u m m a r y}

This paper concerns the transactions which may jeopardise the patrimonial condition of the juridical person. The Author addresses the legal meaning of can. 1295 and practical examples of applying can. 1295. The content of the study shows the historical development of can. 1295, its meaning and the practical application of this norm.

Can.1295 the 1983 Code has its predecessor in can. 1533 CIC/1917. The 1983 Code does not provide an enumerative list of types of acts which should be applied in accordance with can. 1295 but it does state, that the statutes of the juridical person are to conform to the requirements of can. 1291-1294. 
In Poland for example, parishes do not have their own statutes, but they use the statutes of the diocesan synod. For that reason, the postulate de lege ferenda should be applied in order for parishes have their own statutes, by which the requirements of can. 1291-1294 will be observed. It should be added, that the idea of Coetus for the statutes - referred to in can. 1295 - is to be understood in the sense of canon law and consequently recognised by civil law. The aim of this change is to avoid serious mismanagement: when transaction is civilly valid but canonically invalid.

In canon literature, the examples of transactions which may jeopardise condition patrimonium are defined by the following acts: borrowing money; taking out certain mortgages or pledging valuable items as collateral to secure the repayment of a loan; entering into long-term leases; change of status in ownership such as turning over certain property or work to lay management boards; making investments financed by EU projects. These are purely examples of legal acts, as the formulation of a complete list may lead to confusion, as it depends upon the potential impact on the patrimony of the ecclesiastical juridical person.

Key words: transactions, contracts, alienation, administration of ecclesiastical goods

\section{СДЕДКИ, КОТОРЫЕ МОГУТ УХУДЩИТЬ ФИНАНСОВОЕ ПОЯОЖЕНИЕ КОСТЕДЬНОГО ЮРИДИЧЕСКОГО ЛИЦА (КАНОН 1295)}

\section{P е 3 ю м е}

Статья касается сделок, которые могут ухудшить финансовое положение костельного юридического лица. Автор осуществляет анадиз канона 1295 и указывает на практические примеры использования канона 1295. Исследование статьи вкдючает в себя: законодатедьное развития канона 1295, юридическое значение канона 1295, процесс осуществления сделок, которые могут ухудшить финансовое положение, применение на практике и указания разницы между сделками, предвиденных в каноне 1295 и актами чрезвычайной ситуации.

Предшественником канона 1295 КРК/1983 был канон 1533 CIC/1917. Законодатель не подает числительность списка актов, которые следует применять согласно с каноном 1295, но указывает, что уставы костельного юридического лица должны быть приспособлены к канонам 12911294.

В Польше, приходы, как юридические лица, не имеют собственной уставы, вместо этого применяют уставы епископских синодов. Следует добавить, что идея Coetus была, абы уставы, предвиденные в каноне 1295, были поняты в смысле канонического права и последовательно были признаны гражданским правом. Целью этой формулировки было, что- 
бы юридические акты были канонически неважны, а также неважны в государственном порядке.

В литературе канонического права к сделкам, которые могут ухудшить финансовое положение костельного юридического лица предвидены следующие виды актов: затягивание займа, установления ипотеки либо земельный сервитут, кредит под залог ценных вещей, заключение долгосрочных договоров о аренде, изменение в уставе собственности (например, переоформление некоторых форм собственность в общества), поднятие финансовой инвестиции от европейских проектов.

Кдючивые слова: сделки, договора, отчужденность, управление костельным имуществом. 